\title{
社会的共通資本と専門知 鬼怒川水害と「有識者会議」を素材にして
}

\section{梶原健嗣*}

\begin{abstract}
要 旨
「社会的共通資本としての河川」ここで問われているのは「川は誰が管理するのか」というテー マであろう。そして、この問いは「いかに管理するのか」というテーマと密接不可分である。本稿 では、鬼怒川水害とかかわる有識者会議の有り様の中に、このテーマを考える。

2015年 9 月の鬼怒川水害後、2つの有識者会議は動き出した。1つは、上三坂での堤防決壊原 因を検討した鬼怒川堤防調查委員会。もう１つは、鬼怒川河川整備計画を検討する、鬼怒川・小 貝川有識者会議である。「社会的共通資本としての河川」という視角から考える時、重要なのは専 門知の反映という「科学的側面」と民主的な意思の反映・統制という、2つの要素のバランスをど うとるかという側面なのではないかと思う。「民主的コントロール」の視点を欠いた現状の政策形 成は、「閉じた視点」での政策討議にしかならず、結局のところ、問われるべき問題が問われず、却っ て合理性を欠くことになっていないか、というのが本稿の問題提起である。

キーワード : 社会的共通資本、河川法、住民参加、鬼怒川水害、ハザードマップ
\end{abstract}

\section{Iはじめに}

1 社会的共通資本としての河川

\section{（1）社会的共通資本}

社会的共通資本とは何か。社会的共通資本である河川は、 いかに管理すべきなのか。こうした点を確認することから、 本稿を始めたい。

現代経済学では、新古典派経済学が主流派であり、主た る関心は資源の最適分配 $=$ 資源の効率的な利用による効用 の最大化にある。そこでは、幸福 $=$ 効用の最大化 $=$ 資源の 最適分配という等式が前提とされている。

しかし、新古典派経済学は「資源配分の効率性のみを問 題として、所得分配の公正性については問わない」(宇沢 2000、p30)。それは、「分配の公正、貧困の解消という経 済学の本来の立場」(同、p41) から逸脱した、いびつな経済 学の発展であって、これに変わる新しい経済学のパラダイ 厶が求められている。社会的共通資本とは、かかる問題意 識の下で、宇沢弘文が制度主義の考えの下に築き上げた概 念である。その概念は、「新古典派経済学批判と表裏をな して理論化されて」(間宮2015、p78)いったものであった。

新しい経済学のパラダイムは、「資本主義と社会主義を 超えて、すべての人々の人間的尊厳が守られ、魂の自立が 保たれ、市民的権利 ${ }^{1}$ が最大限享受できるような経済体制」 (宇沢2000、はじめに)でなければならない。だから、社 会的共通資本は「一つの国ないし特定の地域に住む全ての 人々が、豊かな経済生活を営み、すぐれた文化を展開し、 人間的に魅力ある社会を持続的、安定的に維持することを 可能にするような社会的装置」であり、その意義は「市民

*愛国学園大学准教授
の基本的権利が最大限に確保される」ことにある(宇沢 2000、p4）。しかし、この定義はやや難解である。包括的 な概念であるため、曖昧さも残る。

宇沢はこうも述べている。「社会的共通資本は全体とし てみるとき、広い意味での環境を意味する」(同、p22)。「社 会全体にとって共通の資産として、社会的に管理、運営さ れるようなものを一般的に総称する」(同、p21)。そして、社 会的共通資本の性格、その建設、運営、維持は、広い意味 での政府、公共部門の果たしている機能を経済学的にとら えたものである」(同。p24)。

周知のように、社会的共通資本は(1)自然環境、(2)社会的 インフラストラクチャー、そして(3)制度資本からなるとさ れる。本稿で主題とする「河川」は明示的に、社会的共通 資本として例示されている(宇沢2010、p19)。なるほど、 これらは確かに、「政府、公共部門の機能」である。

若干、イメージが見えてきた。社会的共通資本とは、資 本主義なかんずく新古典派経済学の弊害と、社会主義の弊 害を越える「第3の道」を可能にするものである。「市民の 基本的権利が最大限に確保される」ことを目的とするよう に、資源の最適分配による効用の最大化ではなく、あくま で「人間的な豊かさ」の確保が目的である。

（2）公共財や公物との違い

宇沢は、社会的共通資本は、「政府、公共部門の果たし ている機能」だとも言う。しかし、それは公共財とは似て 非なるものである。新古典派経済学では、市場こそが最適 な資源配分を可能にするという前提の下で、「例外的に」市 場が効率的に供給できない財を公共財として、政府に委ね るというロジックを立てている。いわば、引き算で「公共財」 
が決まる。その基準は、非排除性、非競合性に求められる のは周知の通りである。新古典派理論の前提に大きな疑問 を持つ宇沢にとって、公共財とは違った概念が必要である。 それが社会的共通資本である。

こうした社会的共通資本は、「政治的プロセス」(宇沢 2000、p4）を経て決定されるものだという。つまり、人々 が地域で暮らす上で、「共通の資産」をステークホルダーが 利害調整し、その利益を享受しようというものであろう。 河川の場合、新古典派経済の観点からも「公共財」とされ、 政府が管理するが、社会的共通資本たる管理は、いわゆる 公物管理とも異なる。

河川法は、「河川は、公共用物」(2条) と定義する。公共 用物とは公物の一種である。ここで公物とは、行政法の講 学的(学問的・概念的) 分類をいい、国または地方公共団体 などにより直接に公の目的に供される有体物をいう。公物 は、道路・河川・港湾のように直接公衆の共同使用に供さ れる公共用物と, 官公署・国公立学校の建物などのように 国または公共団体自身の使用に供される公用物とがある。 実体法上の概念でいうと、公共用物が公共用財産(国有財 産法 3 条 2 項 2 号)、公用物が公用財産(同1号)にあたる。 例えば、私たちが普通に道路を歩くのに、その使用許可を 必要としないように、公共用物はオープンアクセスに供さ れているのがその特徵である。

河川は自然公物として公物の代表例とされるが、公物に は人々の権利性が昰しい。誰にも使用が開かれているオー プンアクセスであるということは、原則として、誰もが独 占的に利用できる権利ではないことをも意味する。法律的 には反射的利益とされ、権利性が否定される。

しかし、宇沢のいう社会的共通資本は、こうした「古い 公物管理概念」とも一線を画しているように見える。西川 潤によれば、社会的共通資本という概念は、「官僚専権の 世界への批判」であって、「経済社会のガバナンスを特権支 配層から民衆の手に奪い返す」(西川2015、p89) ための理 論である。

これを具体的に示すキーワードが、「信託」の概念である。 宇沢は言う、「社会的共通資本の管理、運営はフィデュシ アリー (fiduciary: 受託・信託)の原則にもとづいて、信託 されている」(宇沢2000、p23) と。この点は、極めて重要 な意味をもっていないか。信託とすることによって、公物 の反射的利益のような「権利性の欠如」を克服することが、 宇沢の1つの狙いではないのか2。間宮もまた、社会的共 通資本の意義の1つを、市民としての権利を保障すること に求めている(間宮2015、p79)。

\section{(3) 信託と専門家の関与}

信託的管理を考える宇沢は、職業的専門家による管理を 要求する。即ち、「社会的共通資本の管理を委ねられた機 構は、あくまでも独立で、自立的な立場に立って、専門的 知見にもとづき、職業的規律にしたがって行動し、市民に
対して直接的に管理責任を負うものでなければならない」 （宇沢2010、p20）のである。

では、「職業的規範に従った管理・維持」とはいかなるも のか。また、それは、職業的専門家による「独占」を意味 するものか。そうではなからう。先に、社会的共通資本は、 「政治的プロセス」(同、p4)を経て決定されるものだと述べ た。つまり、地域で人々は暮らす上で、「共通の資産」をス テークホルダーが利害調整し、その利益を享受しようとい うものであるから、職業的専門家による「独占」とは異な るはずである。ステークホルダー間の利害調整において、 専門知が公平な立場から、適切な利害調整を行っていくこ とを求めていると思われる。いわば、専門知による科学的 審理と住民参加による民主的統制のバランスの中で、適切 な公物管理がなされることを求めているのではないかと思 われる。

\section{2 河川法と住民参加}

「専門知による科学的審理と住民参加による民主的統制の バランスの中で、適切な公物管理を実現する」という視点 から現状を考察すると、いかなる評価が出来るであろうか。

現在の河川法は、旧来の工事実施基本計画を(1)マスター プランたる河川整備基本方針(16条) と (2)中期計画に相当 する河川整備計画(16条の2) に分割し、極めて不十分では あるものの、後者に住民参加規定(4項)を盛り达んでいる。

ここで「極めて不十分だ」と言ったのは、主に2 点ある。 即ち、(1)行政の裁量権が強いこと、(2)早い段階での参加で はないこと、である。

河川法では、河川整備計画の作成に当たり、学識経験者 (3 項)、住民 (4項)、関倸知事・市長 (5項) の「意見を聞く」 ことが課せられているが、学識経験者、住民とも、意見聴 取の手続きは「河川整備計画の案を作成しょうとする場合 において必要があると認めるとき」に行われる。この点は、 「あらかじめ、政令で定めるところにより、……意見を 聴かなければならない」とされている関係知事・市長 (5項) と対照的である。即ち、意見の反映が河川管理者の裁量に 委ねられている。

現実に行われている住民参加には、会議の傍聴、公聴会 の開催、パブリック・コメントなど様々なものがあるが、 例えば鬼怒川堤防調查委員会(後述)では、委員が議論する 会議室とは別室にモニターを設置し、そこでモニター画面 を見るという傍聴しか許されていない。完全に、傍聴を「知 る権利」とは位置づけない参加形式となっている。

しかし、河川法と住民参加という観点から言って、より 重要なのは(2)である。住民参加の実効性を高めるためには、 計画の初期段階、まだ様々な選択肢が可能な段階で、この 意思決定に参加することが重要である。しかし、河川法で 規定される参加は、河川整備基本方針が策定された段階で、 即ち治水計画の大枠を規定する基本高水流量等が決定され 
た後での住民参加でしかない。こうした「限界のある住民 参加」が制度化されているという意味に於いて、(2)の意味 はより重いと考える。

それでは、なぜ、基本高水流量等の決定は、住民参加か ら遮断された形で制度設計されているのか。この点につき、 河川法改正時の河川局長であった尾田栄章氏は、河川整備 基本方針は「科学的・専門的な話」であって「専門家の領域」 であると述べている(古谷2009、p11)。

河川法の逐条解説でも、河川整備基本方針は「長期的な 観点から、国土保全のバランスを考慮し、基本高水、計画 高水流量配分等、抽象的な事項を科学的・客観的に定める ものであるから」(河川法研究会編著 2006、p83)、住民参 加は不要であるとし、かわりに「社会資本整備審議会の意 見を聴くことにより、河川管理者の定める河川整備基本方 針の内容の客観性及び科学性が十分に確保される」(同) と 説明している。

住民参加の意義には様々なものがあろうが、その1つに、 現場の知見の反映 ${ }^{3)}$ という利点があろう。しかし、「早い段 階からの参加」を認めないという形で住民参加 $=$ 現場知の 反映を制限する河川法の規定は、現場の知見の反映よりも、 これを離れて、「科学的・客観的に」検討すること方が、利 点は多いと説いているのである。これは、三好規正も言う ように、「住民意見聴取の実施の有無、方法等については 河川管理者の裁量にかからしめられた、いわばパターナリ スティックなものにすぎない」と言える(三好2010、p154)。

\section{3 焦点となる、専門知}

上述の『河川法逐条解説』の説明は、河川整備基本方針 は客観的・科学的に定められる必要があり、そのために社 会資本整備審議会という専門知を活用し、内容の客観性及 び科学性が十分に確保されていれば足りるという説明であ る。それは極めてパターナリスティックな発想であって、 住民参加という民主的なコントロールはむしろ排除される べき事項とされ、民主的統制を正当性の要件とする認識は 見られない。即ち、「専門知による科学的審理と住民参加 による民主的統制のバランスの中で、適切な公物管理を実 現する」という視点は極めてそしいと言える。

しかし、本当に「専門知を活用し、内容の客観性及び科 学性が十分に確保されていれば足りる」のだろうか。民主 的な意思の反映を排除することで、計画の合理性が担保さ れるというのは、事実に即して正しい見方であろうか。本 稿は、この点を検討するものである。

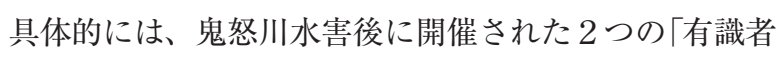
会議」(広義の有識者会議という意味で「」を付した)を検 討することによって、その妥当性を検討する。計画の合理 性や正当性は、専門知や住民意思などがバランスよく反映 されることではじめて確保されるものではないのか。専門 家による検討は、水害という現場から発した当然の疑問を
十分には織り込めず、結局は、視点の不十分な検討になっ てしまうのではないか。本稿は、その点を検討するもので ある。

\section{II 鬼怒川水害と「有識者会議」}

\section{5 年鬼怒川水害}

2015年9月、鬼怒川沿いに発達した線状降雨帯は、鬼怒 川上流・奥日光などで大量の降雨をもたらした。9/8〜 9/10の3日間雨量が10観測地点で600mm を超え、中でもモッ コ平(日光市大字日光字野州原)では、816 mm という大きな 降雨量 ${ }^{4)}$ となった。流域の平均降雨量 (3日間雨量、9/8〜 10)は $502 \mathrm{~mm}$ 、観測史上最多の大豪雨となったというう。

鬼怒川上流部の栃木県内でも日光市や鹿沼市などで大き な被害となったが、被害の中心地は茨城県常総市である。 前述した豪雨の影響で、9月 10 日午後 12 時 50 分頃には、 茨城県常総市上三坂地点 $\left(21 \mathrm{~km}^{6}\right.$ 左岸) で鬼怒川左岸が破堤。 破堤幅は最終的に $200 \mathrm{~m}$ にまで広がり、常総市の約 $1 / 3$ を浸水させた。浸水面積は $40 \mathrm{~km}^{2} に$ に達し、ほぼ江東区と同 じ面積になるという。堤防決壊翌日から始めた Tec-Force(災 害対策派遣隊) の排水活動では、最大51台のポンプ車が投 入され、総排水量は 780 万 $\mathrm{m}^{3}$ にも及んだという。およそ、 東京ドーム $\left(126\right.$ 万 $\left.\mathrm{m}^{3}\right)$ の 6 倍という、膨大な排水量である(国 土交通省関東地方整備局河川部鬼怒川における災害の概 要とその対応」 $\mathrm{p} 20)$ 。緜命な排水活動は、筆者の記憶にも 深い。

利根川水系の破堤 ${ }^{7}$ は、鬼怒川の東を流れる小貝川が 1986 （昭和61）年に決壊して以来、29年ぶりのことである。 水害被害の中心地である常総市では、死者 2 名を含む総計 46名の被害となり、家屋などの被害も、全壊53、大規模 半壊 1,458 、半壞3,525、床上浸水 171 、床下浸水 3,055 に のぼった(国土交通省関東地方整備局、「呯成 27 年 9 月関東. 東北豪雨』に係る 洪水被害及び復旧状況等について」、 2015.12.25)。

しかし、今次の鬼怒川水害の被災地は常総市上三坂だけ ではない。上三坂より約 $4 \mathrm{~km}$ 上流の若宮戸地点(無堤地区) では、 $24.75 \mathrm{~km} 、 25.25 \mathrm{~km}$ の 2 箇所で溢水 ${ }^{8}$ が生じた。ソー ラーパネルが設置されていたのは、25.25km 地点である。

常総市では、更に八間堀川の被害がある。八間堀川は、 鬼怒川・小貝川の間を南北に平行に流れている。同時域は 「沖積層からなる低湿地带」(『水海道市史』 $\mathrm{p} 444$ ) であって、 「豊田谷原」と称され、漁势が行えるほどの小沼が広がって いたという(『石下町史』p405)。これを、1635(寬永12)年、「当 時の関東郡代伊奈備前守忠治の発案により、三坂新田の名 主猪瀬太右衛門らがこれに協力し、豊田郡の悪水落としと して人為的に開削」(同、 $\mathrm{p} 445$ )することによって、新田開 発が可能になったのである。

小貝川と鬼怒川の間を小貝川に注いでいた八間堀川は、 その後、角井・五反田地先で右に曲がり、鬼怒川に注ぐ新 
八間堀川も開削されるようになった。開削は 1700 (元禄 13)年である(『水海道市史』 $\mathrm{p} 446)$ 。鬼怒川合流点直前は、八 間堀川排水機場が置かれ、国交省の直轄区間となっている。

この八間堀川でも、笑生小学校(同市平町) 前を含め、3 箇所で堤防が決壊した。大生小学校は、堤防決壊により高 さ約 $2 \mathrm{~m}$ まで浸水、校舎や電気設備が大きな被害を受けた という(茨城新聞2015.10.25)。

\section{2 鬼怒川堤防調査委員会}

鬼怒川水害から約 3 週間後の 9 月 28 日、国交省は鬼怒川 堤防調查委員会を設置(委員長 : 安田進・東京電機大学理 工学部教授)、水害被害の調查に乗り出した。決壊から 2 日後の 9 月 12 日には地盤工学掞よび河川工学を専門とす る 8 名の委員を決定し、13 日には委員による現地視察を 行ったという(鬼怒川堤防調查委員会2016「はじめに」)。 委員会は、その後、第2回(2015.10.5) 第3回(2015.10.19)、 第4回(2016.3.7) と会議を重ね、3月29日調査報告書をと りまとめた。

筆者も第 1 回、第 4 回の 2 回の会議を傍聴したが、委員会 の検討事項は、上三坂の堤防決壊原因にほほ限定されてい る。報告書 $\mathrm{p} 1-2$ もあるように、(1)基本情報の整理 $\rightarrow$ (2)堤防 決壊区間の被災メカニズムの検証 $\rightarrow$ (3)決壊原因の特定 $\rightarrow$ (4) 本復旧工法の検討が、委員会のテーマである。第 4 回の委 員会では報告書原案が提示され、日本語表現として問題の ある箇所を訂正したのみで、ほぼ原案を了承した。

委員会の結論としては、越水堤防 (越流水深約 $20 \mathrm{~cm}$ ) を 主要な原因と位置づけている。即ち「越水により川裏側で 洗掘が生じ、川裏法尻の洗掘が進行・拡大し、堤体の一部 を構成する緩い砂質土(As1) が流水によって崩れ、小規模 な崩壊が継続して発生し、決壊に至ったと考えられる」と いう。

また、浸透破堤、特にパイピング破堤については「堤体 の一部を構成し堤内地側に連続する緩い砂質土(As1) を被 覆する粘性土 $(\mathrm{Bc}$ 及び $\mathrm{T})$ の層厚によっては発生した恐れが あるため、決壊の主要因ではないものの、決壊を助長した 可能性は否定できない」と、瞹昧な結論に終わった。更に 侵食(洗堀) 破堤の可能性については、侵食痕は確認できず、 原因の可能性は非常に小さいという結論を出した(鬼怒川 堤防調查委員会2016、p3-36)。

\section{3 鬼怒川·小貝川有識者会議}

鬼怒川水害後に開かれた専門家委員会としては、もう 1 つ、鬼怒川・小貝川有識者会議がある。利根川では、利根 川河川整備基本方針（2006.2.14）の策定を受け、流域を5つ のブロック に分けて、河川整備計画作成の検討を 2006 年12月より始めた。しかし、5ブロックの河川整備計画策 定作業は、2008年5月、中断する。中断直前の第 4 回合同 会議(2008.5.23) では、「きょうの御議論を踏まえまして、
次回にはまた御議論いただく基になります整備計画のたた き台を沶しをいたしまして、また、それを説明します」 と関東地方整備局から説明があったにもかかわらず(議事 録p38)、中断した。中断理由については、今もって不明 である ${ }^{10)}$ 。

その後、民主党政権が八ッ場ダム建設事業予算を再計上 (2011.12.22) した際に、官房長官裁定の 1 条件として、利 根川水系の河川整備計画の策定が条件付けられ、利根川 · 江戸川有識者会議が、2012年9月、4年ぶりに再開する。委 員会は、途中9回のキャンセルを挟みながら、7回(第5～ 11 回)の会議を開催。2013年5月には利根川・江戸川河川整 備計画を策定した。

利根川・江戸川河川整備計画策定後も、残り 4ブロック の有識者会議は、なかなか再開されなかったが、鬼怒川・ 小貝川ブロックでは、水害発生後の 2015 年 10 月に会議を 再開。合計 3 回の議論を経て、2016年3月に鬼怒川河川整 備計画を策定した。なお、鬼怒川・小貝川ブロックの有識 者会議であったが、策定された河川整備計画は、鬼怒川だ けである。

さて、この有識者会議で議論されたのは、(1)鬼怒川水害 の概要、(2)整備計画の目標流量などである。河川整備基本 方針で定められた基本高水流量は $8.800 \mathrm{~m}^{3} / \mathrm{s}$ (石井地点)、 100年に 1 回の洪水に対応することを目標とするものであ る。そして、河川整備計画では、2015年洪水の戻し流量 $6,600 \mathrm{~m}^{3} / \mathrm{S}$ (石井)を今後 $20 \sim 30$ 年の目標值として定めた。

\section{III＼cjkstart検討されなかった、3つの課題}

このように、鬼怒川水害後、河川管理者が主催となった 会議が2つ設置された。学識経験者が参加したという意味 で、両者を広義の有識者会議と捉えると、2つの会議を通 じて「問われなかったテーマ」が3つある。それは、(1)常総 水害という視野での検討、(2)八ザードマップの検討、(3)復 旧堤防の妥当性の 3 点である。

\section{1 「常総水害」という視点の欠如}

はじめに、「常総水害」という視点の欠如という問題があ る。これは堤防調查委員会の方に顕著な問題点であるが、 委員会では、上三坂の堤防決壊原因の調査に議論は終始し、 若宮戸地区での溢水についても、八間堀川の問題について も、全く議論をしていない。

若宮戸地区は、上三坂地区からわずか $4 \mathrm{~km}$ 上流。国交 省の直轄管理区間 $(3 \mathrm{~km} \sim 101.5 \mathrm{~km})$ である。鬼怒川では、 河川整備計画に先立って、鬼怒川直轄河川改修事業が定め られ、洪水以前に事業の「再評価」 ${ }^{11)}(2012.1 .11) さ え$ え行わ れていた。この直轄河川改修事業は、整備計画に先立って 今後 $20 \sim 30$ 年で行う事業内容を示して抢り、いくら「み なし規定」 ${ }^{12}$ があるとはいえ、改正河川法の精神を換骨奪 胎するものである。改正河川法では、今後 $20 \sim 30$ 年の河 
川整備の計画は、住民参加の下で策定されるもの (16条の 2 ・ 第4項)であるから、それをバイパスして「実質的な河川整 備計画」を定めることは許されないはずである。

その点も十分大きな問題点ではあるが、しかし、本稿が 問題にしたいのはそのことではない。鬼怒川直轄河川改修 事業では、今後20～30年に行う堤防整備状況を示してい る。p 8 に図 1 が示され、鬼怒川下流部は(1)今後7年間で整 備する区間、(2)今後 $20 〜 30$ 年で整備する区間が示された。 そして、(1)・(2)が示されることによって、実質的に(3)今後 $20 \sim 30$ 年間は整備されない区間の3つが示されている。

今回、溢水が起きた若宮戸地区は、この区分でいうと、 (3)事業不実施区間である。そうであれば、なぜ若宮戸地区 が長年無堤地区にされ、改修事業でも整備計画がなかった かを検討するとともに、若宮戸地区を「他山の石」にして、 他にも不適切な計画区分になっている箇所がないかを検討 することが望まれたはずである。

河川整備計画では、通常、堤防の整備計画を、「堤防の 整備に係る施行の場所」あるいは「堤防の侵食対策に係る 施行の場所」として、具体的に示す。水害後に策定された 河川整備計画でも、表5-1（p27）、表5-3（p29）において示 されているが、有識者会議で議論は行われていない。堤防 調査委員会でも議論はなかったことは、前述の通りである。 堤防調查委員会、有識者会議とも、八間堀川での破堤の 問題も取り上げていない。確かに破堤地区は県の指定管理 区間(河川法9条 2 項) であるが、新八間堀川の最下流部(鬼 怒川合流点）は、僅かだが、国の直轄区間となっている。 それは、そこに国が管理する排水機場があるからである。 八間堀川の破堤水害に関しては、八間堀川の排水機場の操 作が適正だったかは検討されて然るべき話だと思うが、こ の点も全く議論がない。

総じて、2つの有識者会議はともに、常総水害という視 点での検討を行ったものとはいえないのである。

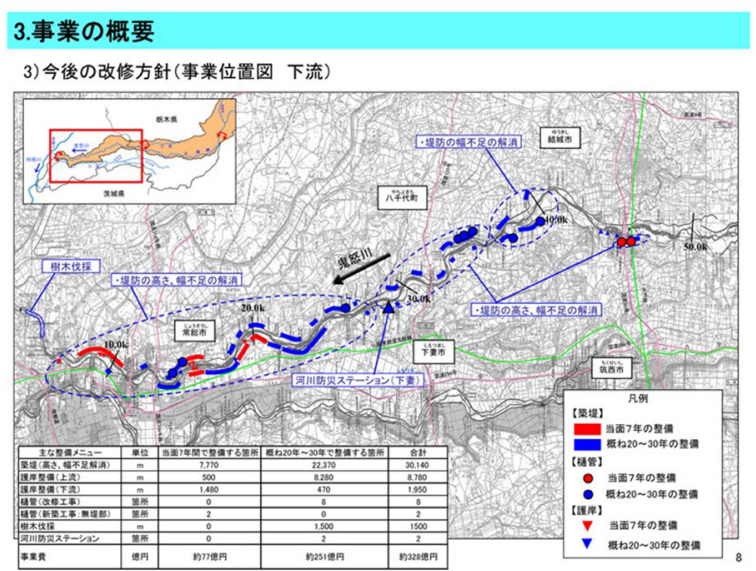

「鬼怒川直軩河川改修事業」(再評価資料、2012.1.11)、p8 図 1 鬼怒川下流部・堤防整備計画
２八ザードマップは当たったのか

もう1つ重要なのは、ハザードマップの検討である。ハ ザードマップ (水防法14条) は2001年の水防法改正で本格 導入されたもので、今日では「減災」の主役ともなっており、 社会的な期待は大きい。水害後に開催された「大規模汇濫 に対する減災のための治水対策のあり方について」(2015 年12月)に㧍いても、「避難行動に直結するハザードマッ プの改良」の必要性が示されている。

右肩上がりの成長は望めない時代にあって、政策決定に おいて、これまで以上に財政的制約のウェートが大きく なってくる。また、財政制約のほかにも環境的制約や社会 的制約も無視できない。そうであれば、「今後の治水のあ り方」では、減災の視点がより強くなるであろうし、その 中で、ハザードマップの重要性は大きくなっていくはずで ある。

だからこそ、ハザードマップの作成・広報において、不 断の改良が望まれる。そしてハザードマップの改良のため には、事前のシミュレーションの妥当性を検討していく作 業が不可欠である。なかなか訪れない「答え合わせ」の時に、 事前予測と実際の乘離を検討することは、ハザードマップ 改良のために、不可欠のプロセスといってよい。しかし、 この検討作業が行われていないのである。

では、鬼怒川水害において、ハザードマップは「当たって いた」といえる代物だったか。図 2 が水害以前に作成された 常総市のハザードマップである。シミュレーションの前提 は、鬼怒川の治水安全度である $1 / 100$ 洪水を見据え、1/100 豪雨 $(=402 \mathrm{~mm})$ 時の水害被害を想定したものである。

八ザードマップでは想定水深を色別に示すが、図 2 から 読み取れる情報は、「左岸は、鬼怒川〜小貝川の間で“薄く 広く”浸水する」というものであり、他方「右岸では浸水深 の差は激しく、全く浸水しない場所もあれば、左岸よりも 深く浸水する場所もある」というものである。図2からは、 深刻な被害が生ずるとしたら、むしろ右岸であるという情 報を読み取るのが普通ではないか。

このように、図2のメッセージを解釈する時、興味深い のは図3である。図3は、直接八ザードマップを示したも のとはいえないが、鬼怒川・小貝川有識者会議において配 布された「参考資料3 鬼怒川に打ける河川整備効果につい て(水害リスクの評価(試行〉)」に揭載されていた資料であ る(第 7 回会議、2015.12.24 : 筆者傍聴)。

汇濫シミュレーションは、左岸 $10 \mathrm{~km} 、 15 \mathrm{~km}$ のつの地 点で行われ、洪水の規模も、整備計画規模 $(1 / 45)$ 、基本方 針規模 $(1 / 100) 、 1 / 200 、 1 / 500$ の段階で整備前／整備後を 検討している。そのため、図 2 と異なり、右岸では全く被 害が生じないシミュレーションとなっている。実際、今次 の水害では右岸に顕著な被害は生じて㧍らず、その意味で は、図3が穾態に近い。図2で示された予測は、結果的に は不正確なものだったと判断すべきではないのか。 
常総市でハザードマップの担当となっている安全安心 課・防災危機管理係に対し、図2のハザードマップの情報 公開を求めたところ、(1)作成者は国交省、(2)洪水規模は3 日間雨量 $402 \mathrm{~mm}^{14)}$ などを示した資料であることが分かっ た。鬼怒川下流部のハザードマップとして、今後は図3が 示されていく可能性は濃厚である。そうだとすれば、図 $2 /$ 図 3 の違いにつき、有識者会議では適切な議論が行われて 然るべきである。

図 3 の推計は、右岸に被害が生じない推計である。こ の変化は、水害を契機に予測手法を変更したことでもた らされたものなのか。シミュレーションの精緻化自体は 歓迎すべきことだとしても、旧手法の問題点など、その 過程は明らかにされて然るべきであるし、専門家による 検証を経る必要があるはずである。しかし、有識者会議 でも堤防調査委員会でも、この点は全く論議されなかっ た。有識者会議が、求められた役割を果たしたとはいえ ない側面である。

\section{3 堤防強化亡裏法の保護}

この点は堤防調査委員会に大きく関わるが、上三坂地 区の復旧堤防は、委員会の決壊原因調查を経て、下記の ように復旧工法が決まったが、現地では不安を感じる人 は多いと聞く。

それは、堤防の裏法面に被覆がないからである。日本 の場合、堤防決壊の原因の8 割以上は越水破堤であって(吉 川2008、p98)、越水破堤では越流した洪水流が堤防裏法 面(特に裏法尻)をえぐり、決壊させてしまうことが多い。 堤防調查委員会の報告書でも、越流破堤(図3-1、p3-1) は「越 流水により裏のり面の崩壊が進む」と説明されている。こ うしたメカニズムは、実験結果でも確認されている知見 である(與田ら2010、p352)。

そうであれば、裏法面の効果的な保護・強化は、防災上、 極めて重要な課題であるはずである。図4に見るように、 復旧計画では堤防天端はアスファルトで被覆され、また 川表面も被覆が施されている ${ }^{15}$ 以上、被覆が効果的な堤防 強化策だと、国は認識しているはずである。しかし、そ うした被覆を裏法面についてはやらないという。また、 その理由を被害者が尋ねても、明確な回答はない。2016 年5月に行われた水害被害者との交渉でもこの点につき、 会場から質問が出たが(筆者傍聴)、国から納得できる回 答は示されていない。

鬼怒川水害の直前の 2015 年 8 月、社会資本整備審議会は、 「水災害分野に扔ける気候変動適応策のあり方について」 を策定している。そこでは、「既に築造されている堤防の 信頼性を向上させる観点も含めて、堤防が決壊に至るま での時間を引き延ばし、避難等のための時間をできる限 り確保することを可能とするような堤防の構造について 検討するべきである」(p26)と、答申している。

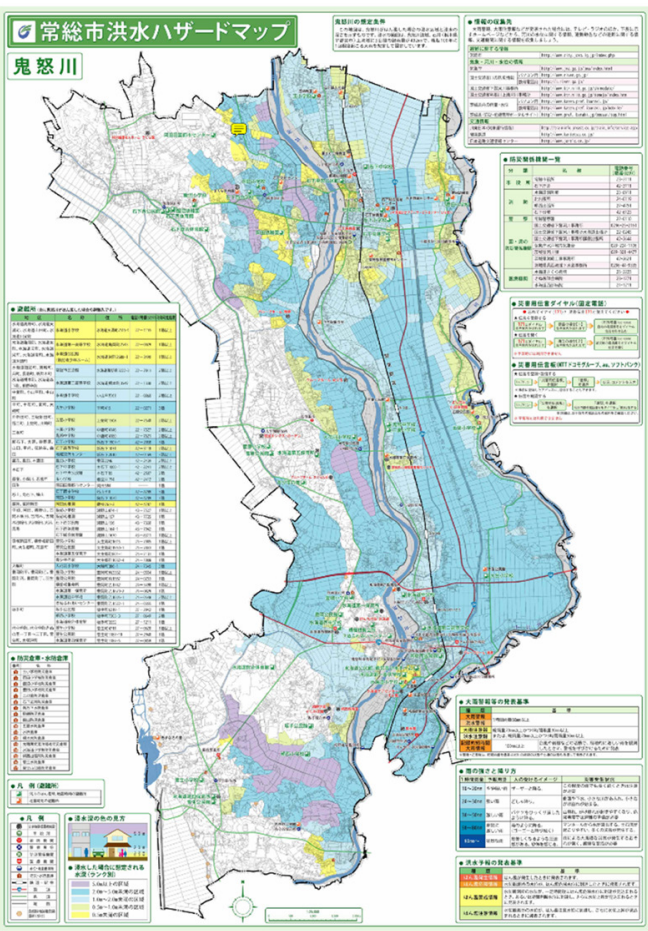

図2 常総市・ハザードマップ（洪水以前）

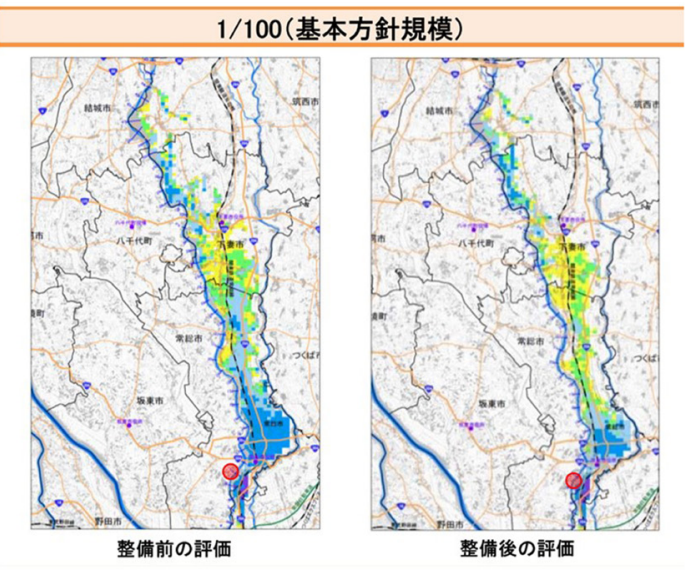

鬼怒川・小貝川有識者会議、第7回配布資料、参考資料 $3(\mathrm{p} 5)$

図３汇濫シミュレーションの結果 （左岸 $10 \mathrm{~km}$ 破堤、1/100 規模）

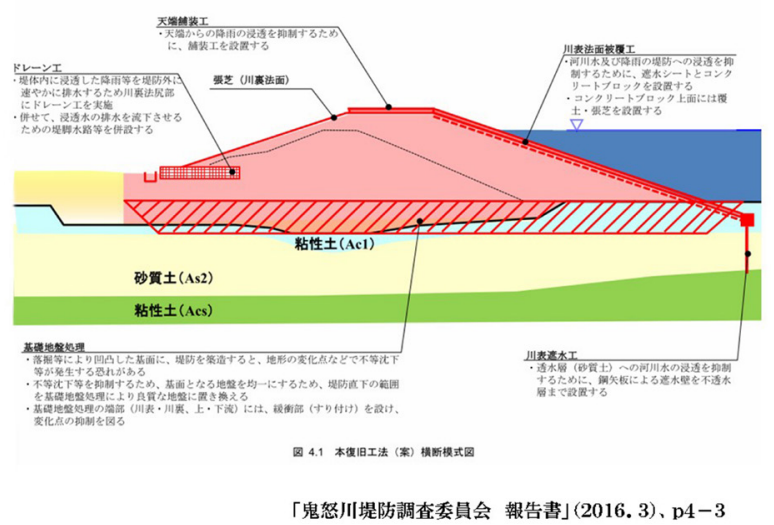

図4 
鬼怒川水害は、この答申後、最初の大型堤防決壊事例で ある。その復旧堤防の工法が、被害者に今もなお不安に思 われている。その点が有識者会議で何の問題視されなかっ たことも、有識者会議に期待された役割からいって、大き な問題ではないのか。

\section{IV おわりに一一科学／民主の二元論を超えて}

世の中には、個々人では対応しきれないリスクがある。 そうした社会的リスクを予防、または軽減することに政府 の存在意義があり、治水事業もまた、水害という社会的リ スクを防備するための社会的対応である。社会的共通資本 とは「政府、公共部門の果たしている機能」であるのならば、 そうした治水事業の対象たる河川もまた、1つの社会的共 通資本 ${ }^{16)}$ であって、そうであれば、「専門知による科学的 審理と住民参加による民主的統制のバランスの中で、適切 な公物管理を実現する」という方法が求められているはず である。

しかし、現状の河川管理は、「公共用物」(河川法 2 条) と しての河川管理であって、住民の権利性が極めてそしく、 「官」に閉じた構造になっている。この「閉じた構造」は、 学識経験者、住民、関係知事・市長に向けて、僅かに開い ているのみである。そして、「僅かな開き」で足りるとする ことの根拠は、専門知の反映によって科学性・客観性が確 保されるという考え方であった。

だが、現場知を反映しない「専門家の検討」は非常に大 きな欠陥を有している。本稿では、鬼怒川有識者会議にお いて、(1)常総水害という視野の欠如、(2)ハザードマップの 的確性の検証の欠如、(3)裏法面を保護(被覆)しない工法の 検証欠如という形で、現場知・住民の不安 / 疑問を反映し ない形になっていることを指摘した。これでは、地域で人々 は暮らす上で、「共通の資産」をステークホルダーが利害調 整し、その利益を享受しようとする「政治プロセス」になっ ていないのではないか。「鬼怒川有識者会議」のあり方は、 そのことを雄弁に物語っており、専門知と民主的統制のバ ランスという視野に立つ、「社会的資本としての河川管理」 の重要性を物語っていると考える。

\section{注}

1）宇沢は、アメリカからの帰国後に上梓した『自動車の社会 的費用』の中で、道路がいかに市民の基本的権利を侵害し ているかを問題にしている。社会的共通資本において、 その目的に市民の基本的権利の確保・享受を問題にする のは、この帰国後の「原体験」に由来しているのだろう。

2) この点で、宇沢の信託概念はいわゆる公共信託論の一種 であるとも言える。公共信託論とは英米法の概念で、 Joseph.L.Sax が的確にまとめている。即ち、水や大気など の自然資源は現代・将来の世代から政府に適正な管理が 託された資産であって、政府はその趣旨に基づく適正な 管理を行わなければならないという考え方である。

3）淀川水系流域委員会では、「地域の特性に詳しい委員」あ るいは「住民連携委員」として、地域で住民運動に関わっ
てきた人々の広範な参加を求めた。これは、地元で日常 的に河川と接しているからこそ有している独自の情報が あるという評価を基礎にしている。

4）水文水質データベース（国土交通省、http://www1.river. go.jp/)。

5）これまでの最高值は、2001年に記録した402mm である(「鬼 怒川の流出計算モデルについて」p314)。

6）鬼怒川のような支川の場合、本川の合流地点を基準に距 離を測る。

7）利根川・江戸川本川では、1949年のキティ台風時に破堤 して以来、破堤被害は生じていない。

8）越水と溢水の違いについては、堤防の設置されている場 所で洪水が堤防を乗り越える時に越水、無堤地区で河川 から洪水が溢れる時に溢水と表現するのが一般的である (http://www.cbr.mlit.go.jp/kisojyo/explanation/)。

9）5ブロックは、(1)利根川・江戸川、(2)渡良瀬川、(3)鬼怒川・ 小貝川、(4)霞ヶ浦、(5)中川・綾瀬川の(5)ブロックである。

10) 中島政希衆議院議員 (当時)の質問主意書 (2012.2.2)におい ても、この点が質問されたが、回答は答えを留保してい る(2012.2.10)。

11） 1 度目の事業評価は 2011 年 3 月である。

12) 河川法改正(1997) 時、「正式に河川整備基本方針が策定さ れるまでは、工事実施基本計画を暫定的な河川整備基本 方針として扱う」という附則が織り达まれた。

13）予測の誤りの原因として考えられる要因は、スライドダウ ン計算の介在である。堤防幅が計画に満たない場合に、 実際の堤防高を過小評価する修正計算方法で、スライドダ ウン計算により河川の流下能力は過小評価される(梶原 2014、p331-332)。

14) 今回の洪水を受けて、鬼怒川の $1 / 100$ 雨量は $495 \mathrm{~mm}$ に修 正されるが、それまでは、402mm とされていた。

15) 堤防完成後、筆者は堤防完成見学会に参加した(2016.5.29) が、確かに図4の通りの堤防復旧が行われている。

16）宇沢は随所で、社会的共通資本の「提供するサービス」「社 会的規準による使用」という表現を用いている。それは、 社会的共通資本」もまた、1つの「資本」であることに由 来しよう。だが、そうした「資本」的な特質を社会的共通 資本の本質的な要素であると考えると、河川には特殊な 側面があるかもしれない。それは、河川は「水の恵み」を もたらすだけでなく、「水の災い(水害)」をももたらすと いう両義性である。後者の側面を有する存在を、普通は「資 本」と言わないのではないか。この点は、同じ自然環境と いえども、森林のような私的便益(木材の提供など) と公 益的機能 (水害緩和など)をもたらし、「社会的共通資本の 利用」、社会的共通資本のもたらすサービス」などをイ メージしやすい自然とでは、同一に扱えない側面もある かもしれない。

\section{参考文献}

磯部力 (2012) 新版行政法, 放送大学出版会.

宇沢弘文(1974) 自動車の社会的費用, 岩波書店．

宇沢弘文 (2000) 社会的共通資本, 岩波書店。

宇沢弘文 (2010) 社会的共通資本としての川を考える, 宇沢弘 文・大熊孝編著, 社会的共通資本としての川, 東京大学 出版会, 19-30.

宇沢弘文 (2015) 宇沢弘文の経済学——社会的共通資本の論理, 日本経済新聞社, 45-127.

宇沢弘文・茂木愛一郎 (1994) 社会的共通資本——モンズと 都市, 東京大学出版会, 15-45. 
梶原健嗣 (2014) 戦後河川行政とダム開発一一利根川水系にお ける治水・利水の構造転換, ミネルヴァ書房 .

河川法研究会編著 (2006) 改訂版 · 逐条解説 河川法解説, 大 成出版社.

国土交通省関東地方整備局河川部 (2016) 鬼怒川における災害 の概要とその対応，河川，2016.1.

水防法研究会編著 (2005) 逐条解説 水防法, ぎょうせい. 西川潤 (2015) 社会的共通資本 (SOC) とコモンズ, 現代思想, 43 (4).

間宮陽介 (2015)社会的共通資本の思想，現代思想，43(4). 三好規正 (2010) 水循環と流域ガバナンスの視点からの公物管 理法制のあり方一一水利権制度を中心として，山梨学院 大額法学論集, 65 .

安田進 (2016) 国土交通省の鬼怒川堤防調査委員会における検 討事項, 河川, 2016.1.

吉川勝秀 (2008) 河川堤防学, 技報堂出版.

與田敏昭ほか $(2010)$ 越流侵食・浸透のメカニズムを把握する ための小型堤防による越流侵食実験，河川技術論文集， 16 .
Joseph.L.Sax (1971) Defending the Environment-A Strategy for Citizen Action, ALFRED A.KNOPF, New York, (1971) 邦訳 山川洋一郎・高橋一修, 環境の保護一市民のための法的 戦略一, 岩波書店, 1974 .

行政資料

石下町 (1988) 石下町史, 405-412.

河川審議会計画部会 $(2000)$ 流域での対応を含む効果的な治水 のあり方，中間答申， 2000.12.19.

鬼怒川堤防調査委員会 (2016) 鬼怒川堤防調査委員会 報告書 国土交通省河川局治水課 (2005) 洪水ハザードマップ作成の手 引き。

国土交通省関東地方整備局 (2015) 鬼怒川の流出計算モデルに ついて.

国土交通省関東地方整備局 (2016) 鬼怒川河川整備計画．

社会資本整備審議会 (2015) 水災害分野における気候変動適応 策のあり方について

水海道市 (1983) 水海道市史(上巻)，377-388,439-452. 